\title{
ANALYSIS OF BATIK SEMARANG BUSINESS PERFORMANCE USING SCP (STRUCTURE-CONDUCT-PERFORMANCE) APPROACH
}

\author{
Ngatindriatun ${ }^{1}$ \\ 'Faculty of Economics and Business, Dian Nuswantoro University, Central Java-Indonesias
}

\begin{abstract}
Batik Semarang is one of Indonesia's national heritage, which once had disappered in Japan colonialism era. In 2006, the city government of Semarang started to redevelop Batik Semarang as a regional identity of Semarang, by conducting a preservation program of Batik Semarang. This research's objective is to identify and analyze the business performance of Batik craftsmen or batik maker in Semarang focused on the study on production, distribution, and market aspects. The fact arose is the decreasing number of Batik craftsmen year by year. The research was conducted by using the survey method on 17 batik craftsman in Semarang city. The Analysis of Batik Semarang's Business Performance uses SCP approach which covers market structure analysis, conduct analysis, and performance analysis. The industry level market is moderately concentrated over the study indicated by the CR4 $75 \%$ and HHI 1889. The result of market structure analysis suggest an oligopolistic market structure. Performance analysis involves the elements of price conduct, product conduct, and market conduct. Price conduct shows that $76 \%$ of respondents act as the price maker. Product conduct shows that $70 \%$ of respondents have chosen to do product diversification. Market conduct shows that 56 percent of producers sell the products directly to the consumers.. Performance analysis is viewed from the element of Batik business profitability, which shows the average $\mathrm{R} / \mathrm{C}$ ratio of 1.72 and the average ROA of 0.51. This indicates that Batik Semarang business is still profitable.
\end{abstract}

Keywords: Batik, SCP, Production, Distribution, Performance, Market, Semarang.

Received: 8 January 2014/ Revised: 22 January 2014/ Accepted: 10 February 2014/ Published: 10 March 2014

\section{INTRODUCTION}

Batik, has been known since 17th century, is one of Indonesian heritages that needs to be preserved. In 2009, Indonesian batik has received recognition as a world's heritage from United Nation's UNESCO. Batik is a supreme product every region and city in Central Java has, mostly managed by micro-scale enterprises. It is the same case with Batik Semarang. Batik Semarang, or more widely known as 'Batik Semarangan', was once a triumph in Batik market, as well as Batik Solo and Batik Pekalongan. Nowadays, however, its triumph has been fading over time. According to Batik Semarang researcher, Yuliati (2009), Batik village before Japan colonialization was the centre of Batik in Semarang. However, the tradition of creating Batik in Semarang Batik Village was discountinued when Semarang became a warzone in the Japan colonialization and 
post-independence era. The fire that burned Batik village in Japan colonialization era has its role in the disappearance of Batik Semarang. Beside the lost of cultural art that the city of Semarang has, the opportunity of generating profit from the currently growing Batik business also occurs (Disperindag Kota Semarang, 2011).

In the beginning of 1980, the effort of redeveloping Batik village has been done, but has failed to sustain. In 2006, the local government of Semarang, by Dekarnas (Dewan Kerajinan Nasional) Semarang city, tried to revive Batik Semarangan that was short on batik crafstmen/batik maker. One of the efforts done by Deskranasda is to redevelop Batik village as the centre of Batik production, by organizing various trainings for the people of Batik village. The effort of the government in making the area of Batik village being in the cultural heritage area is reflected in local regulation (Perda) No. 14 Year 2011 about the city layout plan of Semarang.

When looking at the strategies done by Semarang city government and Dekranasda, both physical and non-physical, those still do not succeed in improving Batik village and in training the craftsmen. Because of that, the effort to revive Batik village in Semarang as a production centre that has been done since 2006, is not making any significant development (www.antaranews.com, April 26th 2012).

According to a research by Anisyah and Atmanti (2011), the problem faced by Batik Semarang craftsmen, among others, are minimum capital, limited human resource (from the aspect of formal education, knowledge, and skills), weak business network and the marketing ability, limited input materials for production, and the low number of productive craftsmen. The objective of reviving Batik village is actually not only for Batik Semarang to be one of national heritages, but also to bring back the glory and popularity of Batik village in Semarang by empowering Batik craftsmen to produce high-quality Batik. Therefore, the performance of Batik Semarang business needs to be increased.

The empowerment that has been done is still not conducted effectivelly. The empowerment is still focused on finding new craftsmen by Batik workshops and trainings. However, after the trainings have been conducted, the craftsmen still do not continue their business, and this caused low productivity. On the other hand, Batik Semarang craftsmen have limitations in accessing: market informations, market scope, business network, and strategic business locations. Most craftsmen only market the products around Semarang area, in not very strategic locations, so that even people in Semarang are still not very familiar with Batik Semarang. Looking from capital perspective, most of Batik Semarang craftsmen are also facing the same problem faced by many micro businesses. It can be shown by the small business scale that use their own capital, which is small in amount. The linkage between production and crafstmen's business performance that have not been done countinuously will cause inefficiency in production and poor distribution.

From the explanation above, it is necessary for a study of analysis of Batik Semarang business performance to be done, in order to determine some kind of policy to increase the performance of 
Batik Semarang craftsmen, so that the welfare of Batik Semarang craftsmen can be increased and the existence of Batik Semarang can be in the same level with other kinds of Batik that have already went popular in Indonesia.

\section{MATERIAL AND METHOD}

Batik is a process of painting texts or ornaments in any media using wax as color-barrier instrument (Prasetyo, 2010). In the making batik, the wax is applied to fabric to prevent the color absorption during the coloring process. Nevertheless, common people know Batik as a kind of fabric that has some unique traditional pattern. In other words, common people know Batik as a pattern, not as a technique of fabric painting. According to Yudoseputro (2000), Batik is a fabric drawing made using wax as a media and a cover of the fabric. Another view stated that Batik is a cloth with drawings, made by special technique of drawing by wax on the cloth and the processed in a particular method (Wulandari, 2011).

Batik industry in Indonesia is mostly consisted of small and medium scale businesses. The existence of these small and medium businesses has already become a support and hope of most of Indonesian people to reduce poverty, unemployment, and income distribution gap. Therefore, it is the same case with the industry of Batik in Semarang.

The definition of UKM (small and medium enterprises according to Badan Pusat Statistik (BPS), or Indonesian statistics organization, is based on the quantity of human labors. Small scale enterprise is a business entity that hires 5-19 workers, while medium scale business is a business entity that hires 20-99 workers. The Indonesian Ministry of Cooperatives and Small and Medium Enterprises stated a different definition of this, as well as according to indonesian Law No. 20 Year 2008. Those definitions are shown in Table 1.

Table-1. The Criteria of UKM Based on Assets and Omzet

\begin{tabular}{lllll}
\hline No & Enterprises & $\begin{array}{l}\text { According to Ministry of } \\
\text { Cooperatives and Small and } \\
\text { Medium Enterprises }\end{array}$ & According to Law No 20 Year 2008 \\
\cline { 3 - 5 } & Assets & Omzet & Assets & Omzet \\
\hline \multirow{2}{*}{ Small } & $<200$ Million & $<1$ Billion & 50 Million - & 300 Million -2.5 \\
& & & 500 Million & Billion \\
\hline 2 & Medium & $\begin{array}{l}200 \text { Million }-10 \\
\text { Billion }\end{array}$ & 500 Million - & 2.5 Billion -50 \\
& & & 10 Billion & Billion \\
\hline
\end{tabular}

Source: (Menengah, 2008)

This research uses the theory of industrial organization from Martin (1994) as the grand theory, which focuses on the relationship of Structure-Conduct-Performance. This theory is used because the theory itself is quite simple, yet representative to explain the phenomenon which happens in UKM Batik Semarang. The SCP relationship is shown in Figure 1. 
Figure-1. The Interactive structure-conduct-performance market framework

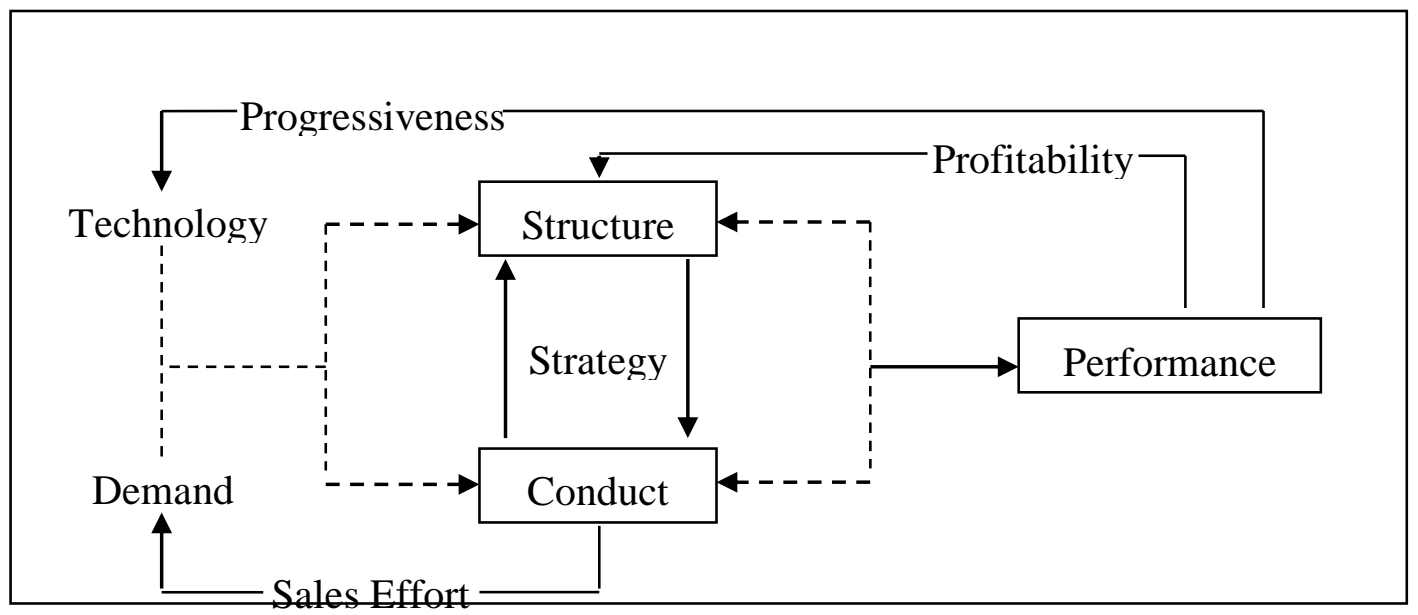

Source : (Martin, 1994)

Figure 1 shows that the structure and conduct are influenced by demand and technology condition. Structure influences conduct, yet conduct (especially the strategic one) also influences structure. This means that structure and conduct interact together in determining performance. Next, sales efforts as one of the elements of conduct give feedback and influence demand. In turn, performance also gives feedback to structure and technology. Progression is a driving facor in technology innovation, while the profit level determines the attraction to enter the market and has dynamic effect on structure.

As the complement for the grand theory of Martin, the argument from Shepherd is used, as shown in Figure 2.

Figure 2 shows that the structure and conduct influence maket performance. Good performance including low price, efficiency, innovation, and fairness. Basic condition represented by elasticity of demand can observe structure: the greater elasticity of demand, the more a market structure has a tendency to be concentrated. The more concentrated market structure, among others, will cause a tendency on price stickiness. This may create an impact on market conduct. Martin (2002) summarizes this framework approach suscintly:

"The central hypothesis (of the SCP framework) is that observable structural characteristics of a market determine the behavior of firms within that market, and that the behavior of firms within a market, give structural characteristics, determines measurable market performance". 
Figure- 2. Industrial Organization : Structure-conduct-market performance Approach

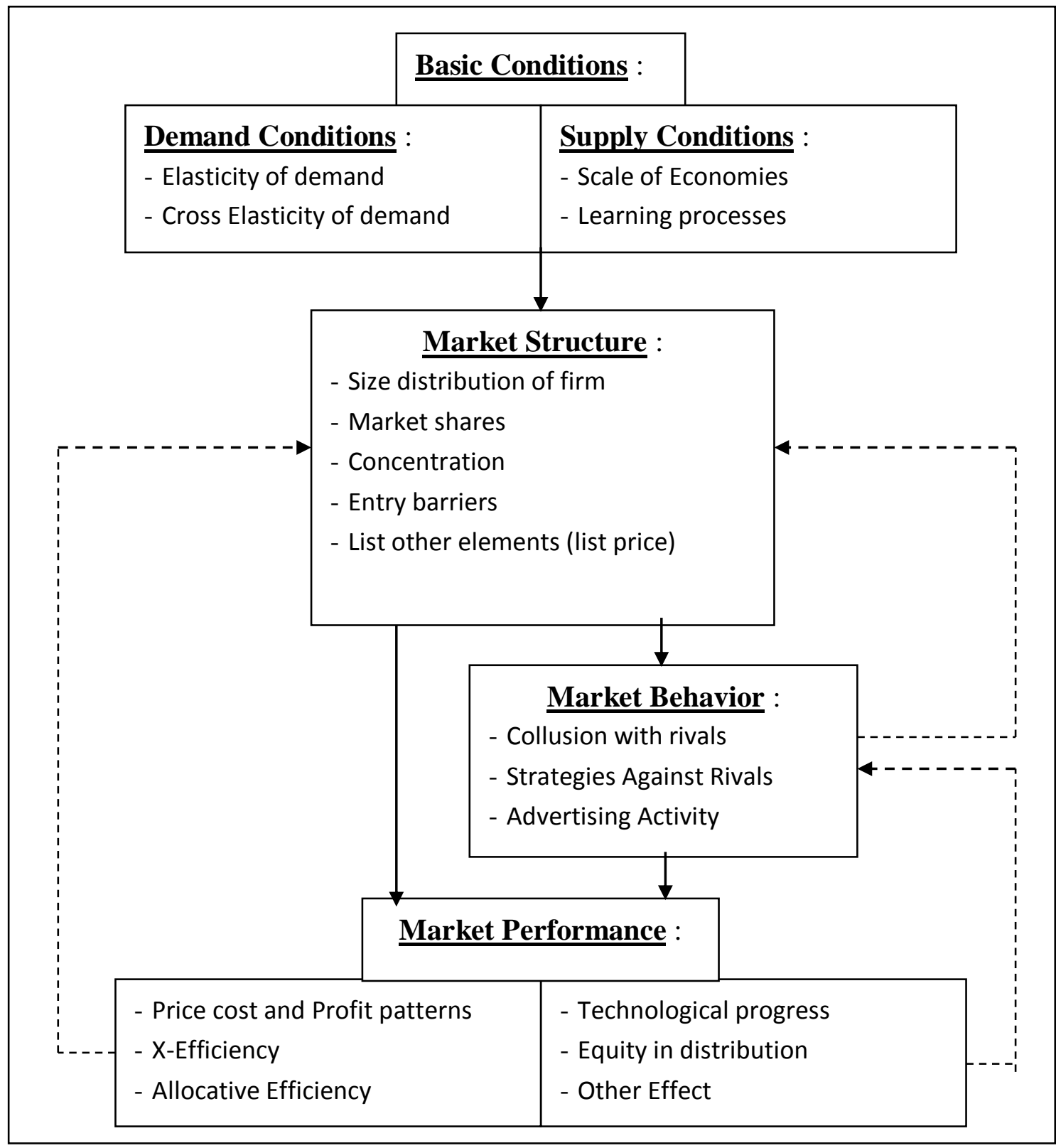

Source : Shepherd (1990)

The paradigm of Structure-Conduct-Performance depends a lot on the conduct of buyers and sellers (demand and supply). This conduct depends on the market structure which is influenced by basic conditions. These basic conditions are the ones which will influence the Structure-ConductPerformance of the people by getting through the stages. 
The structure and conduct of the market that is shaped would be influenced a lot by the market's early conditions. Structure would influence conduct, yet conduct would also influence structure. Structure and conduct then would together influence market performance.

Next, the market performance that is formed would influence market condition. Then, the performance would influence the existing market structure and basic conditions.

The industry performance is usually measured by market control or the amount of profit generated by a company in an industry. The elements of performance, according to Heather (2002), are: (1) profitability, (2) efficiency, (3) economic growth, (4) full employment, and (5) equity.

This research was conducted in UKM Batik Semarang which located in several sub-district areas, such as South Semarang, East Semarang, West Semarang, Mijen, Gunung Pati, Pedurungan, Genuk, Tembalang, Gajah mungkur, and Banyumanik. The research was conducted by using the survey method on 17 respondents of Batik Semarang crafstmen. The method used was based on the result of questionnaires and interview. Questionnaires were distributed in order to get the data about description of respondents and respondents' performance which covers the aspects of production and distribution. These two aspects cover market structure, conduct, and performance.

\subsection{Analysis of UKM Batik Semarang's Performance}

The survey data was gathered by using questionnaires as a tool and Batik Semarang craftsmen as respondents. This analysis is used for conducting performance analysis of UKM Batik Semarang. The performance analysis of UKM is explained through the relationship between the structure, the conduct, and performance of UKM. This analysis is started from looking at the market structure of UKM Batik Semarang: wheter it is monopoly, oligopoly, monopolistic competition, or perfect competition. This market structure will influence conduct of the company/industry, therefore can influence industry performance.

\section{RESULT AND DISCUSSION}

The analysis of Batik Semarang business performance in this research discuss the aspects of production/business, distribution, and market absorbtion. According to SCP (Structure-ConductPerformance) approach, the analysis has the sequence of: (1) analyzing market structure through the quantity of distribution and supply chains; (2) analyzing conduct through the components of price conduct and production strategy; and (3) measuring performance through profitability.

\subsection{Structure}

Industry structure is a reflection of market structure in an industry. Market structure reflects the level of competition in a Batik industry. The market structure of an industry can be viewed 
from the number of sellers. Size of firm can be viewed from sales, assets, or labors compared to total industry, and this is called market concentration. Using $\mathrm{N}$-firm concentration ratio, market concentration of Batik Semarang shows the ratio (CR4) of $75 \%$. This points to oligopoly market structure. This market structure shows high concentration level and low numbers of producers. This ratio is supported by Herfindahl Hirschman Index calculation of 1889. The value between 1000-2500 is considered oligopoly market (Hasibuan, 1993).

One of many barriers in entering the market is the existence of big companies that are already in the market. To see how much is the barrier to entry in an industry, an economic scale is used. According to Lipczynski (2005), economic scale plays a role of barrier to entry if the Minimum Efficiency Scale (MES) is relatively greater than total industry or when the company in industry operates in the level of average cost that is lower than MES. The value of MES of Batik Semarang industry is quite high, which is $40 \%$. The high MES value (>10\%) will be a barrier to new competitors to enter the market of Batik Semarang.

\subsection{Conduct}

Conduct is an industry's response and adjustment pattern in a market in order to reach its objectives (Hasibuan, 1993). Indicators used in this research are price conduct and production strategy.

In the indicator of price conduct, the research shows that in term of determinant of price, majority of respondents stated that the price of Batik is determined $76 \%$ by producers. This means that producers have influence to determine the price. This caused by the conduct in determining the price of Batik according to its pattern. The products made are art products that have their own uniqueness compared to other similar products. The more complex and beautiful the pattern of the Batik, the price will also be more expensive, especially Batik tulis (handwritten Batik).

In the indicator of product strategy, research shows that the producers of Batik Semarang doing business diversification is as many as $70 \%$ (12 respondents). The objective in doing diversification are to expand and develop the business can expand and develop the business. More variation on products means bigger market; each new product may give better market opportunity for the business to expand. Diversification also means more product alternatives for customers in order to compete with other competitors.

Another result is regarding supply chains. The result shows that $56 \%$ of Batik producers sell their products directly to the customers, especially in Batik exhibitions. The other $28 \%$, before the products are received by end-users, are distributed first by wholesalers, while the other $16 \%$ are distributed to sellers. It can be concluded that supply chains used by Batik Semarang producers are mostly direct distribution. 
In advertising, Batik Semarang businessmen mostly rely on exhibitions. $70 \%$ of respondents often promote their Batik through exhibitions held by government institutions such as Deskranasda Semarang.

\subsection{Performance}

Performance can be measured by the profitability level. The profitability level is the ability of a company or industry in making profit with the utilization of its capital. The profitability level of furniture industry corresponds with its industry scale. This research uses two approaches in order to analyze profitability level: $\mathrm{R} / \mathrm{C}$ ratio and Return on Assets (ROA).

$\mathrm{R} / \mathrm{C}$ ratio is a calculation of total revenues divided by total costs. The bigger an $\mathrm{R} / \mathrm{C}$ ratio, the more profitable it becomes. ROA is the level of profitability from assets. In this research, the average $\mathrm{R} / \mathrm{C}$ ratio is 1.72 and the average $\mathrm{ROA}$ is 0.51 . These results indicate that the business of Batik Semarang is still profitable.

\section{CONCLUDING REMARKS}

\subsection{Conclusions}

1. The market structure of Batik Semarang shows oligopoly market, which is shown by the value of CR4 of $75 \%$ and the value of MES exceeding $10 \%$. This shows the existence of barriers to enter the market of Batik Semarang.

2. The price conduct is mostly determined by producers. This is related to the uniqueness Batik products have. The price of Batik depends on the pattern of the Batik itself, especially Batik tulis.

3. The performance of Batik Semarang shows that the business of Batik Semarang is still profitable. This is indicated by the ROA value of 0.5 and $\mathrm{R} / \mathrm{C}$ ratio of 1.72 .

\subsection{Recommendations}

1. Batik Semarang craftsmen need to develop their products, so that the products can compete with other types of Batik, from the aspects of price and quality. The objective is so that Batik Semarang can be at least equal to Batik from other regions, such as Batik Pekalongan and Batik Solo.

2. The government needs to play its role in the effort of increasing the performance of Batik Semarang craftsmen, so that small-scale craftsmen are able to produce more and continuously in order to compete with larger-scale Batik Semarang businesses. This will lead the market structure to become monopolistic. 
Funding : This study received no specific financial support.

Competing Interests: The author declares that there are no conflicts of interests regarding the publication of this paper.

Contributors/Acknowledgement: We express our highly appreciation to Ariati Anomsari, Hertiana Ikasari (from) the Faculty of Economics and Business, Dian Nuswantoro University and Milchazena V.D (from) Gadjah Mada University for valuable sharing and editing of this paper.

\section{REFERENCES}

Anisyah, Y. and H.D. Atmanti, 2011. Analisis Perkembangan Industri Batik Semarang, Semarang: $\begin{array}{llll}\text { Universitas } & \text { Diponegoro } & \text { (UNDIP). } & \text { Available }\end{array}$ http://eprints.undip.ac.id/32448/1/jurnal_analisis_perkembangan_industri_batik_semarang.pdf.

Disperindag Kota Semarang, 201 1. UU No. 20 Tahun 2008 Tentang Usaha Mikro, Kecil, Dan Menengah. 26 April 2012. Available from www.Antaranews.com.

Hasibuan, N., 1993. Pemerataan dan Pembangunan Ekonomi Teori dan Kebijaksanaan. Palembang: Universitas Sriwijaya Press.

Heather, K., 2002. The economics of industries and firms. Financial times. Prentice Hall.

Lipczynski, J., 2005. Indistrial organization: Competition, strategy, policy. 2nd Edn., Essex: Pearson Education.

Martin, S., 1994. Industrial economics, economic analysis and public policy. 2nd Edn., New York: Macmillan.

Martin, S., 2002. Advance industrial economics. Massachusetts: Blackwell Publisher Inc.

Menengah, K.D., 2008. Undang-Undang Republik Indonesia Nomor 20 Tahun 2008 Tentang Usaha Mikro, Kecil Dan Menengah.

Prasetyo, A., 2010. Batik Karya Agung Warisan Budaya Dunia. Yogyakarta: Pura Pustaka.

Shepherd, W.G., 1990. The economics of industrial organization. 3rd Edn., Prentice Hall.

Wulandari, A., 201 1. Batik Nusantara. Yogyakarta: CV Andi Offset.

Yudoseputro, W., 2000. Jejak-Jejak Tradisi Bahasa Rupa Indonesia Lama. Jakata : Yayasan Seni Visual Indonesia.

Yuliati, D., 2009. Mengungkap Sejarah dan Motif Batik Semarangan. Semarang: Universitas Diponegoro Semarang. 